\title{
Sound and Fury
}




\section{Also by Eric Alterman}

Who Speaks for America? Why Democracy Matters in Foreign Policy (1998)

It Ain't No Sin to Be Glad You're Alive: The Promise of Bruce Springsteen (1999) 


\section{Sound and Fury}

The Making of the Punditocracy

\section{Eric Alterman}


Lyrics from "Johnny 99" copyright (C) 1982 by Bruce Springsteen/ASCAP. Used by permission.

\section{Copyright (@) 1999 by Eric Alterman}

All rights reserved. Except for brief quotations in a review, this book, or parts thereof, must not be reproduced in any form without permission in writing from the publisher. For information, address Cornell University Press, Sage House, 512 East State Street, Ithaca, New York 14850.

First published 1992 by HarperCollins Publishers First HarperPerennial edition published 1993 First printing, Cornell Paperbacks, 1999

Printed in the United States of America

Cornell University Press strives to use environmentally responsible suppliers and materials to the fullest extent possible in the publishing of its books. Such materials include vegetable-based. low-VOC inks, and acid-free papers that are recycled, totally chlorine-free, or partly composed of nonwood fibers. Books that bear the logo of the FSC (Forest Stewardship Council) use paper taken from forests that have been inspected and certified as meeting the highest standards for environmental and social responsibility. For further information, visit our website at unw.cornellpress.cornell.edu.
Library of Congress Cataloging-in-Publication Data

Alterman, Eric.

Sound and fury: the making of the punditocracy I Eric Alterman.

$$
\text { p. } \mathrm{cm} \text {. }
$$

Includes bibliographical references and index. ISBN 0-80| 4-8639-4 (pbk)

I. Journalism--Political aspects--United States. 2. United States--Politics and government--20th century. 3. Mass media-- Political aspects--United States 4. Television and politics--United States. 5. Press and politics--United States. 6. Talk shows-United States. I. Title. PN4888.P6A48 1999

071 '.3--de21

DNLM/DLC
Paperback printing

$\begin{array}{llllllllll}10 & 9 & 8 & 7 & 6 & 5 & 4 & 3 & 2 & 1\end{array}$

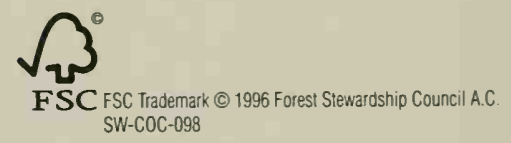


TO MY PARENTS AND TO THE MEMORY OF THEIR PARENTS

לִדר וָדר 
